\title{
Impact of Merger \& Acquisition on Organizations
}

\author{
S.Praveen, Suneetha Rani Tatineni
}

\begin{abstract}
Merger \&Acquisition are the strategies which usually companies and organizations do for increasing their profitability. If a company wants to establish their business in new country, that company shall have three options first option is to start from scratch setting up business, the second option is to have a strategic tie-up with a company which is doing similar business and the third option is to acquire company which is already having presence where the company shall get readymade business with customer base. The mergers and acquisitions are happening across the globe. This paper deals with the purpose of mergers and acquisition and the strategies along with case studies of India and international platforms.
\end{abstract}

\section{INTRODUCTION}

Mergers and acquisitions (abbreviated as M\&A in business circles) are inevitable events in the corporate word; they happen all the time. Mergers are transactions or arrangements where two (or more) separate entities come together to form larger corporations. Acquisitions on the other hand are transactions whose end result is a company fully owning another through purchase of majority shareholding or complete purchase of the assets of the target entity. In other words, mergers occur when two companies agree to go forward as one entity, whereas acquisition results in one company establishing itself as an owner of another. There are two types of acquisition: public or private, where the distinction depends on whether the 'target' was listed or not. If the targeted company is listed with stock exchange of the respective country, then the Acquisition or merger is called as public acquisition. it is a public acquisitionor merger; and if the target is not a listed company with stock exchange then it is called as private acquisition or merger.

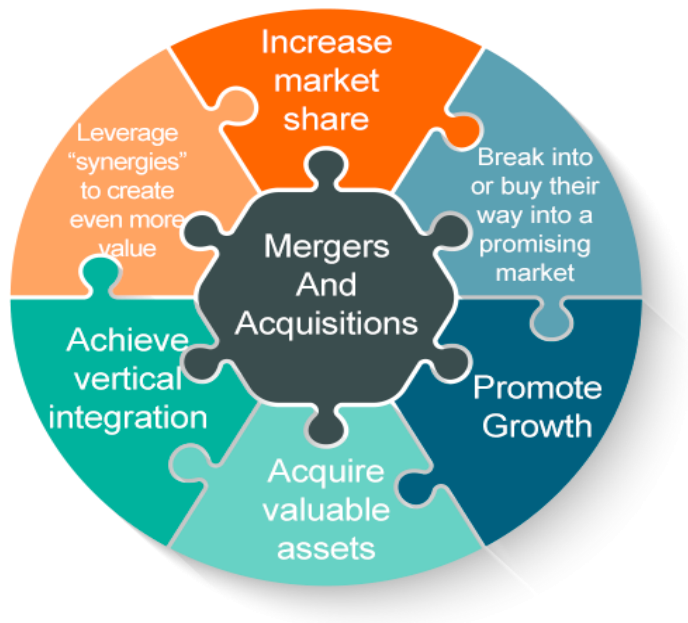

Mergers can be classified into three categories which are called as Horizontal Mergers, Conglomerate and Vertical Merger. Horizontal mergers are strategic decisions taken by management to increase their market share to stay ahead in competition from their competitors. If we can discuss with an example, Banking and Insurance are the two different industry segments but they work together as a part of merger, if we see multi-national insurance companies when they launched their products in India they have started working with Indian companies like HDFC Ergo, Bajaj Allianz, HDFC Standard etc. The Vertical merging strategy is a merging, where companies who have huge a product variants and chain are merged, for example retailer and supplier. This vertical merging usually happens to gain advantage in the distribution of their products. If we observe the case study of merging between Turner Corporation which do TBS, CNN etc., programming and Time Warner Ins which is a cable operation company.For example, a merging between Time Warner Inc which is into cable operations and the Turner Corporation (which produces CNN, TBS, and other programming). Finally, conglomerates are formed when two entities in completely different lines or industries merge. This is done to make rapid fluctuations in earning smoother as well as provide a more consistent existence of the company.
Revised Manuscript Received on October 05, 2019.

S.Praveen, MBA,(Ph.D, Associate Professor, Department of Management Studies, PSCMR College of Engineering and Technology, Vijayawada, A.P., India.(E-mail: praveensama86@gmail.com)

Suneetha Rani Tatineni, Research Scholar, K.L.University, Vijayawada, A.P., India.(E-mail: sudheersunee6727@gmail.com) 


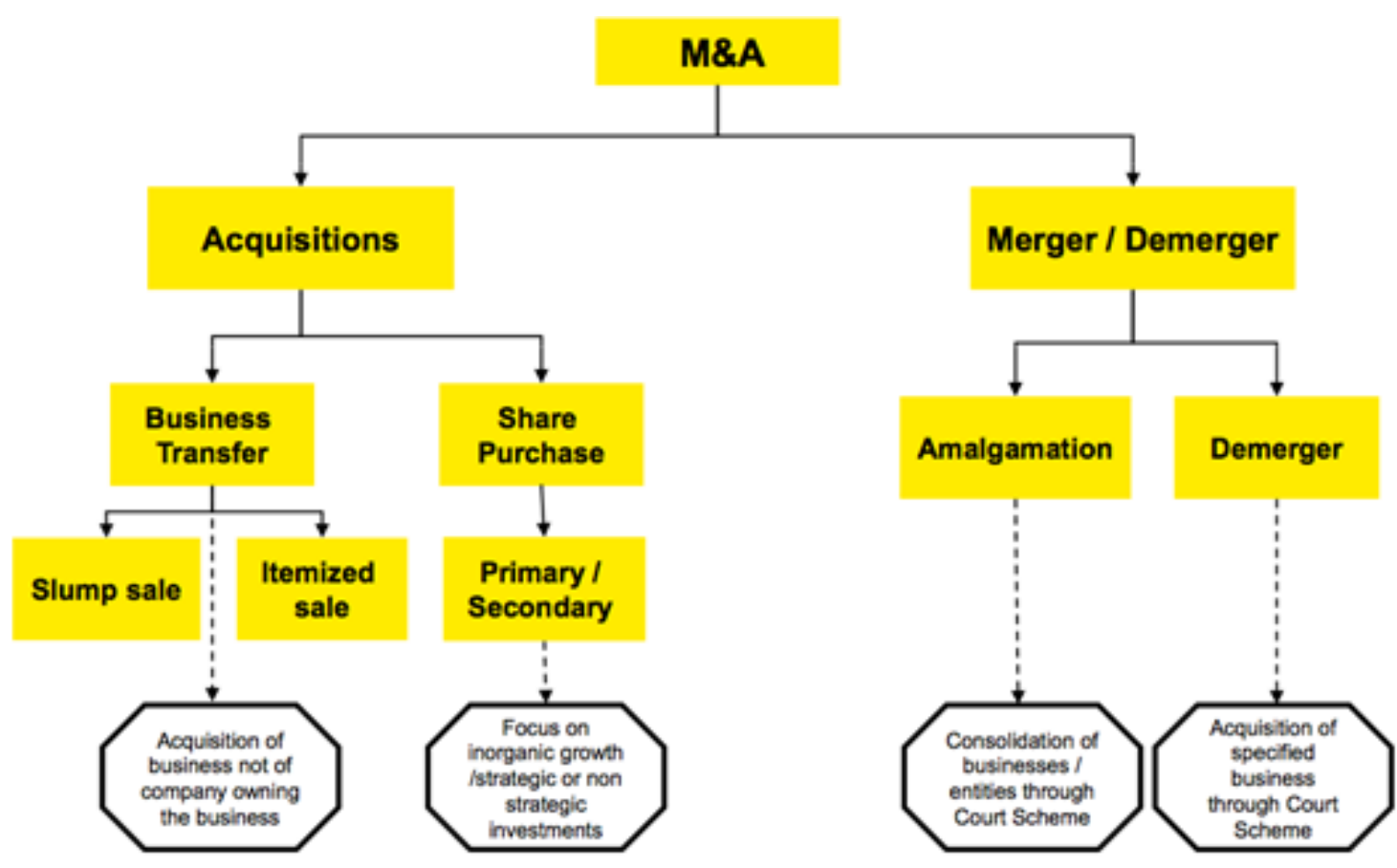

Generally,Mergers happen to achieve specific targets like increasing market share, revenue, profitability etc., which are business centric and there are few other strategies like compliance and corporate governance etc., Finally, overall costs of capital are far much lower for mergers than for separate companies. Synergy value increase in mergers due to reduction in costs because the result of mergers is much smaller departments such as Human Resources (HR), Accounting and Information Technology (IT), which make the resulting entities incur less operation costs. Mergers are able to bargain for lower prices for supplies when they operate as a larger entity than as separate entities (Megginson, 2008, p560).

One of the most well publicized mergers in the American corporate history is the merger between Exxon and Mobil, which were merged to form ExxonMobil. The deal was worth $\$ 80$ billion, the result of which was a large corporation that almost rivaled the world's richest oil producing nations. It is reported that the resulting merger had in excess of 21 billion barrels of oil in their reserves. It was literally the third largest company in the world after General Electric and Microsoft, with a combined capital base in excess of $\$ 237$ billion, but currently the largest company in the world by revenue according to Forbes. The merger, according to the executives of both companies, was to tackle the oil crisis at the time and to compete much more effectively in the oil business.

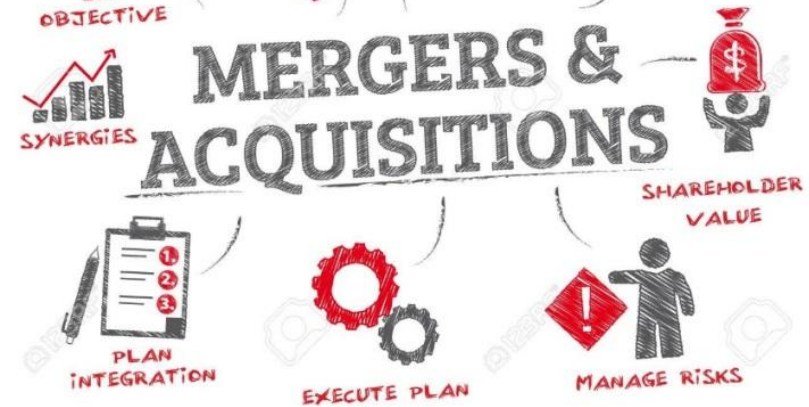

A good example of a local American company with no history of mergers is Associated Grocers of the South Inc. According to their website, they were established in the year 1927 by a group of grocers from Birmingham, Alabama in the US, who decided to combine their efforts to counter the effect of larger retail chains on their businesses. Their aim was to remain relevant to continue serving their customers in supplying low cost and high-qualityproducts. They have grown overtime from operating a 2500 square feet warehouse to facilities made up of over 455,000 square feet of warehouses and administrative space.

\section{REASONS FOR THE MERGER BETWEEN EXXON AND MOBIL}

It is estimated that two-thirds of mergers globally fail. With that in mind, it would bring the question: was the ExxonMobil merger worth it? During the time when the

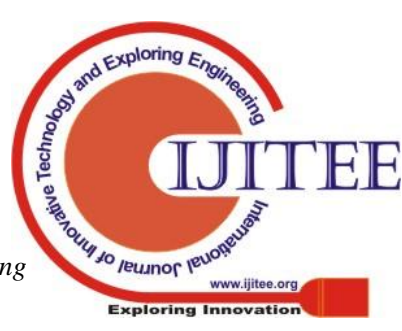


merger was announced, in 1999, the global oil prices were at the all-time and the costs of operations were high. There was therefore a need to consolidate their operations in order to increase efficiency in the fast-changing world, where there were globalizations of companies. Their merger was meant to enter the global oil industry. According to the managers of the companies, another reason for the merger was that the strengths of the companies were complementary and that the result would not only benefit shareholders but also the customers. Both companies had respective and nonoverlapping interest in West Africa, Russia, South Africa, and North America.

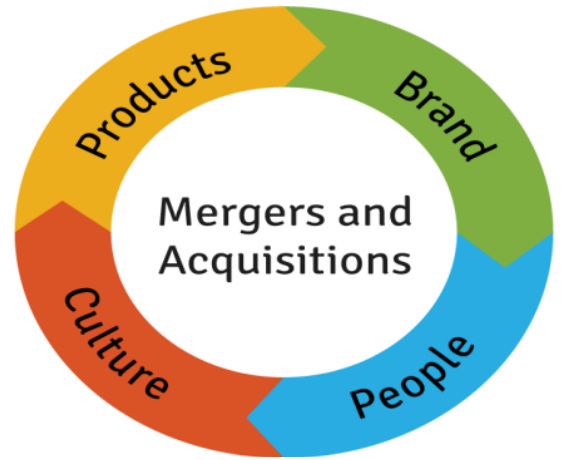

There are justifications of the merger between the abovenamed companies; first being the fact that the resulting merger expanded their market share across the regions mentioned above. This led to ExxonMobil controlling vast oil wells in the world. At the time of the merger, her oil production rivaled oil producing companies of the world. The other justification is that there was more efficiency that resulting from the merger. For instance, at the time of the merger, it was projected that there would be huge savings in terms of economies of scale (Dash, 2008, p5). For instance, the merger resulted in a cut of up to $\$ 2.8$ billion (in economies of scale), with a cut of up to 9000 jobs from 123,000 jobs of the resultant mergers. Those were great saving considering the challenges of the time. There was also a projected reduction in capital spending of up to $\$ 8$ billion since there would be a removal of overlapping expenses in their balance sheets.

The other justification was that there were disturbances in the oil market: there were falling oil prices and rising costs of doing business at the time. It would be wise if those disturbances were tackled by combining efforts in facing them. The merger would have a better access to better markers to their oil.

Another positive thing about the merger was the magnitude of the entity that arose; ExxonMobil become the third company in the world and the largest oil company in the world. Its oil production was third to Saudi Arabia and Iran with reserves in excess of 21 billion barrels of oil and a capitalization of $\$ 237$ billion. Also, in justifying the reasons for the merger strategy, it's worthwhile to look at their performance, 14 years down (Kumar, 2012, p398)

\section{MOST VIABLE CANDIDATE FOR MERGER WITH ASSOCIATED GROCERS OF THE SOUTH INC}

In my view, the most viable merger with Associated Grocers of the South Inc would be Western Supermarkets. Western Supermarkets is situated in Birmingham, Alabama and was founded in 1948. It is one of the largest locally owned supermarkets in Alabama. The reasons for this choice is that first, the produce of Associated Grocers of the South is perishable in nature and that it would be cost effective to sell it locally.

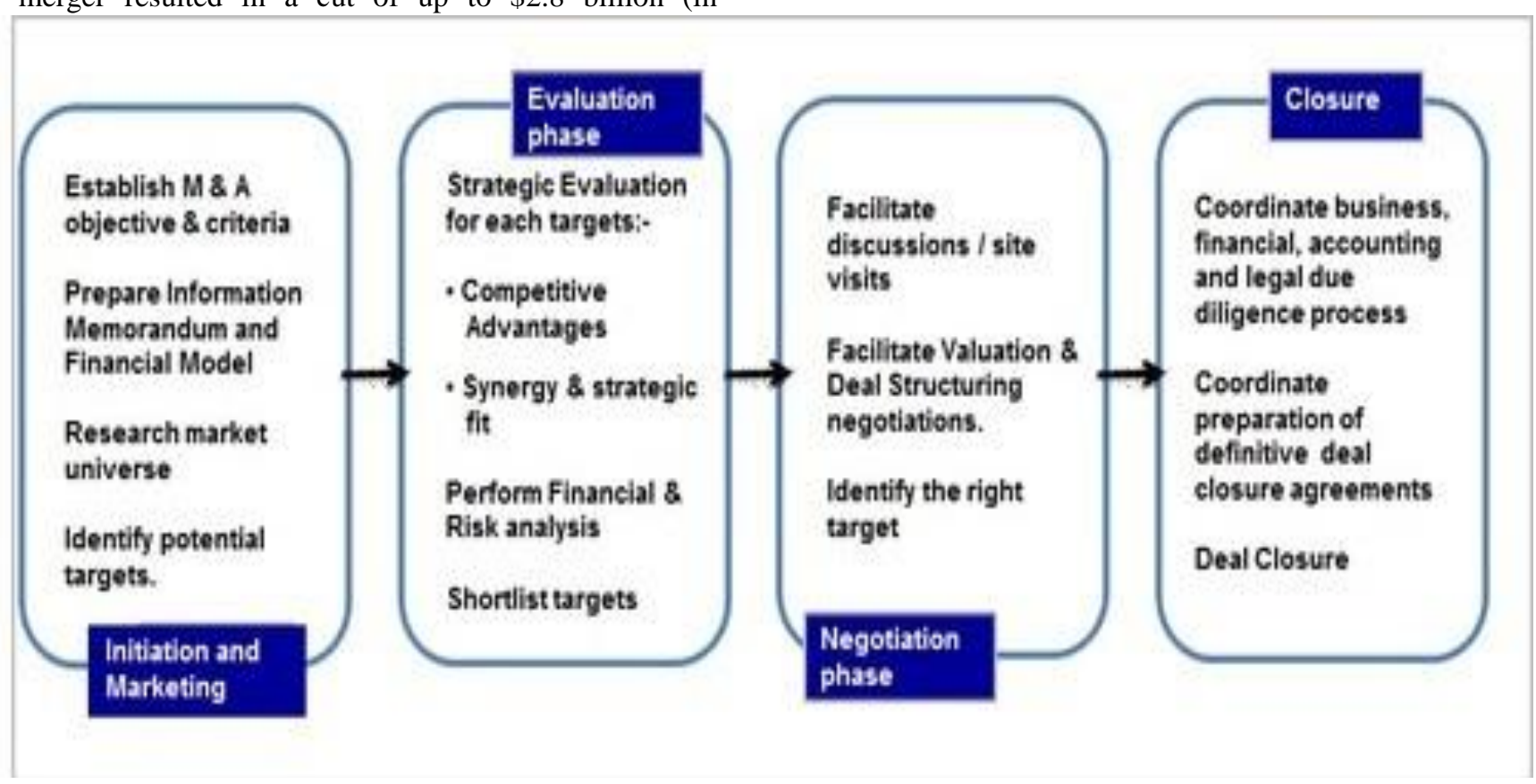


The other reason why this merger is viable is because it would be a vertical merger in the sense that Associated Grocers of the South are producers of groceries while Western Supermarket would be the distributers. This places them in one line of supply chain this would be strategic because while Associated Grocers of the South concentrates on producing grocery products, Western Supermarkets would concentrate in the marketing the products and retailing them. This would make operations more efficient because each entity would concentrate in what they do best. Also, the people's lifestyle is likely to favor the existence of a merger. It would be more efficient for most people to shop in one place than shop at a supermarket for some products then proceed to a grocery shop to shop for groceries.

\section{BUSINESS AND CORPORATE LEVEL STRATEGIES OF EXXONMOBIL}

First, ExxonMobil intends to increase their global footprint across the globe into new markets in Asia, such as China, with intentions to set up world class projects in such markets. This is because of the increase in demand from such markets. It is projected that China will form a junk of its demand market, to a tune of $25 \%$ in 2018.

There are also plans to diversify within the energy sector with the investment in the construction of ethane steam crackers in Singapore, Qatar and Fiji. This combined with setting affiliates with local Saudi companies (for example Saudi Basic Industries Corporation, SABIC) to serve emerging local and international petrochemical markets. These strategies ensure that their survival in the oil and the energy sector remains secure and that their presence will continue to be felt across the globe.

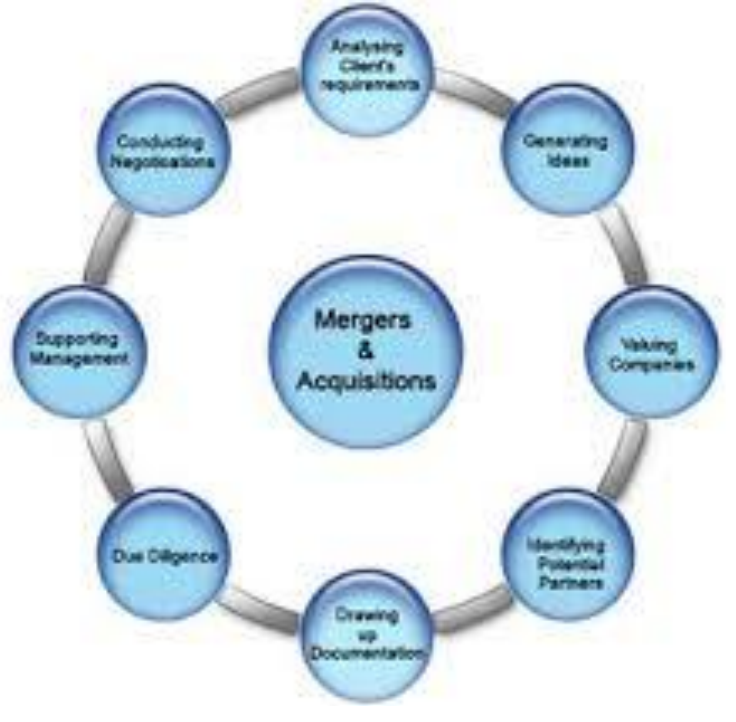

This (especially setting up of affiliates in the Middle East) can be justified because it is more favorable to maintain their presence through affiliates due to local laws. It is much more efficient to operate businesses in partnerships with local companies because the administrative costs will be cheaper. ExxonMobil need to buy shares in local companies and leave administrative tasks to the local companies. Also, it is justified to diversify their investment in new markets (such as the Chinese) because China is a growing industrial nation with a huge demand for oil. Also, their diversification from Coal as a source of energy means that they will bring a huge demand which needs to be filled. This opens up more opportunities for ExxonMobil.

\section{RECOMMENDATION FOR EXXONMOBIL}

Recently, more African countries have discovered oil. Examples include Kenya and Uganda. It would be a better strategy to find a way to these markets through acquiring stakes with local companies or seeking contracts to refine the produced oil. For instance, Uganda tries to find a way to have a refinery within their country whereas Kenya needs to increase their capacity, those are opportunities to expand into new virgin markets and hence maintain their global dominance in the petroleum industry.

\section{STRATEGIES OF ASSOCIATED GROCERS OF THE SOUTH INC. AND THEIR JUSTIFICATION \& RESULTS}

Important plan and the strategy of Associated Grocers of the South Inc. has been and is to expand their operations across Alabama to enable them effectively combat the competition from retail chains; this is in fact the reason why they were set up. This has been seen in their consistent expansion from a small 2500-square foot store to one of the leading groceries in Alabama. This is Justified because an increase in their operations will enable them to access more credit, and at the same time experience economies of scale.

I would recommend however that they consider strategic mergers preferably with retail chains within Alabama, for the simple reason that since their produce is perishable, it would be cheaper hence more profitable to sell the produce locally, preferably through retail shops, like supermarkets. 
International Journal of Innovative Technology and Exploring Engineering (IJITEE) ISSN: 2278-3075, Volume-9, Issue-1, November 2019

\section{Largest M\&A Transactions Worldwide}

\begin{tabular}{|c|c|c|c|c|c|}
\hline Rank & Year & $\begin{array}{l}\text { Acquirer } \\
\text { Name }\end{array}$ & $\begin{array}{l}\text { Target } \\
\text { Name }\end{array}$ & $\begin{array}{l}\text { Value of } \\
\text { Transaction } \\
\text { (in bil. USD) }\end{array}$ & $\begin{array}{l}\text { Value of } \\
\text { Transaction } \\
\text { (in bil. EUR) }\end{array}$ \\
\hline 1 & 1999 & $\begin{array}{l}\text { Vodafone } \\
\text { AirTouch PLC }\end{array}$ & $\begin{array}{l}\text { Mannesmann } \\
\text { AG }\end{array}$ & 202,7 & 204.7 \\
\hline 2 & 2000 & America Online Inc & Time Warner & 164,7 & 160,7 \\
\hline 3 & 2013 & $\begin{array}{l}\text { Verizon } \\
\text { Communications } \\
\text { Inc }\end{array}$ & $\begin{array}{l}\text { Verizon } \\
\text { Wireless Inc }\end{array}$ & 130.2 & 100.5 \\
\hline 4 & 2007 & $\begin{array}{l}\text { Shareholders (Spin } \\
\text { out) }\end{array}$ & $\begin{array}{l}\text { Philip Morris } \\
\text { Intl Inc }\end{array}$ & 107.6 & 68.1 \\
\hline 5 & 2015 & $\begin{array}{l}\text { Anheuser-Busch } \\
\text { Inbev SA/NV }\end{array}$ & $\begin{array}{l}\text { SABMiller } \\
\text { PLC }\end{array}$ & 101.5 & 92,3 \\
\hline 6 & 2007 & RFS Holdings BV & $\begin{array}{l}\text { ABN-AMRO } \\
\text { Holding NV }\end{array}$ & 98.2 & 71,3 \\
\hline 7 & 1999 & Pfizer Inc & $\begin{array}{l}\text { Warner- } \\
\text { Lambert Co }\end{array}$ & 89.6 & 85.3 \\
\hline 8 & 2017 & Walt Disney Co & $\begin{array}{l}21 \text { st Century } \\
\text { Fox Inc }\end{array}$ & 84.2 & 72.5 \\
\hline 9 & 2016 & AT\&T Inc & $\begin{array}{l}\text { Time Warner } \\
\text { Inc }\end{array}$ & 79,4 & 72.9 \\
\hline 10 & 2019 & $\begin{array}{l}\text { Bristol-Myers } \\
\text { Squibb Co }\end{array}$ & Celgene Corp & 79.4 & 69,7 \\
\hline
\end{tabular}

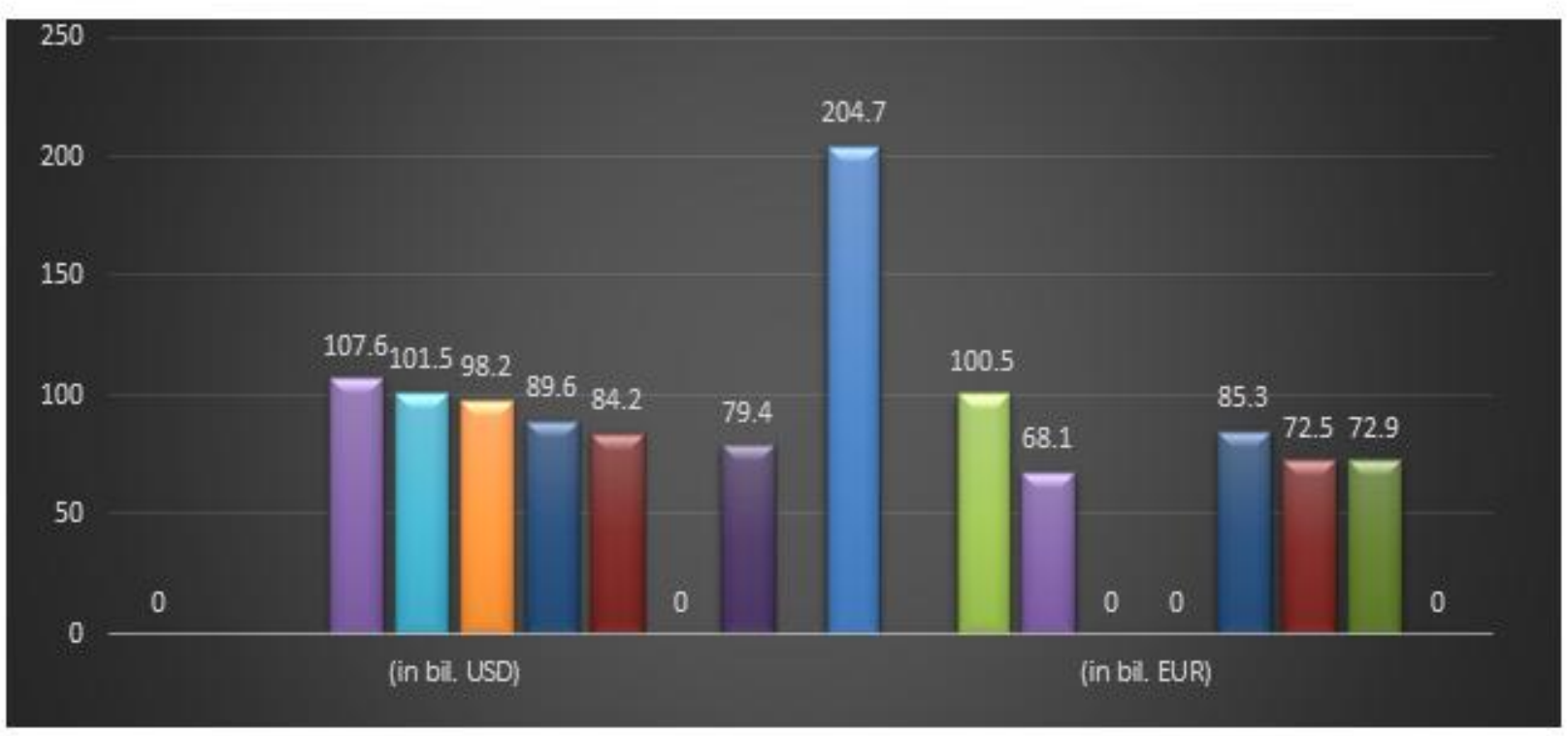




\section{CONCLUSION}

With the global trend in globalization, mergers are inevitable. Acquisitions are inevitable as well due to the challenges in the markets which make some companies existence at risk. The success of the mergers however would be guaranteed if the steps are taken to ensure that the mergers are in compliance with laws such as Anti-trust laws (Hunt, 2007, p181). Giant companies arise out of mergers, like in the case of ExxonMobil. Such companies capture the attention of regulatory bodies which try to ensure that competition exists in the market to prevent an event of market failure. It would be better if the mergers resulting conduct their business in a way that does not try to eliminate competition in the market so as not to cause the reversal of the merger - the splitting of the resulting entity, as it happened to Standard Oil Corporation Company in 1911. The trend is on positive side compared to joint venture rather than Merger \& Acquisition. Companies also moving strategically to reap the benefits from merger or Acquisition. The major acquisitions include whats app to face book etc.,

\section{REFERENCES}

1 Dash, A. (2010). Mergers and Acquisitions. New Delhi: I.K. International Pub. House.

2 Hunt, P. (2007). Structuring mergers \& Acquisitions: A Guide to Creating Shareholder Value. New York: Aspen.

3 Kumar, B. (2012). Mega mergers and Acquisitions: Case Studies from Key Industries. Houndmills, Basingstoke, Hampshire New York: Palgrave Macmillan.

4 Megginson, W. (2008). Introduction to Corporate Finance. London: Cengage Learning EMEA 